\title{
Grazing in the heterotrophic dinoflagellate Oxyrrhis marina: size selectivity and preference for calcified Emiliania huxleyi cells
}

\author{
Frank C. Hansen, Harry J. Witte ${ }^{*}$, Jutta Passarge ${ }^{* *}$ \\ Netherlands Institute for Sea Research, PO Box 59, 1790 AB Den Burg, The Netherlands
}

\begin{abstract}
Selective grazing on nanophythoplankton by the heterotrophic dinoflagellate Oxyrrhis marina was investigated in laboratory experiments. O. marina was offered 2 mixtures of differently sized algae: (1) Micromonas pusilla (2 $\mu \mathrm{m}$ Equivalent Spherical Diameter), Emiliania huxleyi $(5 \mu \mathrm{m}$ ESD), and Tetraselmis suecica ( $7 \mu \mathrm{m} \mathrm{ESD);} \mathrm{and} \mathrm{(2)} \mathrm{Nan-}$ nochloris sp. (2 $\mu \mathrm{m}$ ESDI. Isochrysis galbana (5 $\mu \mathrm{m}$ ESD). Rhodomonas sp. (8 $\mu \mathrm{m}$ ESD), and Tetraselmis sp. $(10 \mu \mathrm{m}$ ESD). O. marina grazed selectively on the larger algal species (ESD $\geq 7 \mu \mathrm{m}$ ), and also selected for the larger cells within each species. O. marina discriminated against E. huxleyi. To test this selection, O. marina was offered mixtures of equal concentrations of the similarly sized algae E. huxleyi and $I$. galbana. In these mixtures, $O$. marina preferred the calcified $E$ huxleyi cells over noncalcified E. huxleyi cells and discriminated against $I$. galbana. This result is also interpreted in terms of size-selective grazing.
\end{abstract}

KEY WORDS: Protozoa - Food selection - Prey size - Microphytoplankton Coccoliths

Heterotrophic dinoflagellates are now recognized as a ubiquitous, important component of the pelagic protozoan community that feeds on pico- and nanophytoplankton (Lessard 1991). Size-selective grazing in protozoans (Fenchel 1980, Jonsson 1986, Rassoulzadegan et al. 1988) has been examined; however, little is known about the food preferences of heterotrophic dinoflagellates (Hansen 1992).

The widespread species Oxyrrhis marina was used as a model organism to study selective grazing in an omnivorous phagotrophic dinoflagellate. O. marina, which can reach high abundances in rockpools and salt lakes, has also been found in the White Sea, the western Baltic, the English Channel and in the Mediterranean Sea (Kofoid \& Swezy 1921). This species has been reported to feed on a wide range of particle sizes, from small algae like Nannochloris oculata (2 to $4 \mu \mathrm{m}$ )

-Addressee for correspondence. E-mail: harryw@nioz.nl

-Present address: Dept of Microbiology, University of Amsterdam, 1018 VS Amsterdam, The Netherlands to algae as large as O. marina itself, like Cricosphaera elongata (20 to $30 \mu \mathrm{m}$ ) (see Droop 1966). On the other hand, O. marina also seems to be able to discriminate between food species (Tarran 1992). The experiments presented here were designed to test (1) size-selectivity in O. marina grazing and (2) whether or not E. huxleyi may form an exception within its size class. In contrast to most previous dinoflagellate grazing studies, we used mixtures of food items.

Material and methods. Oxyrrhis marina and the algal species were obtained from the NIOZ culture collection (Netherlands Institute for Sea Research, Dept Biological Oceanography). They were grown semicontinuously in batch cultures in autoclaved $\mathrm{f} / 2$ medium (Guillard \& Ryther 1962 ) at $15^{\circ} \mathrm{C}$ and illuminated $16 \mathrm{~h}$ light: $8 \mathrm{~h}$ dark with $60 \mu \mathrm{E} \mathrm{m} \mathrm{m}^{-2} \mathrm{~s}^{-1}$. O. marina was fed Isochrysis galbana and Rhodomonas sp.

In 3 incubation experiments Oxyrrhis marina (18 $\mu \mathrm{m}$ Equivalent Spherical Diameter, ESD) was offered different mixtures of algal species (Table 1). The experiments were performed in $600 \mathrm{ml}$ glass bottles mounted on a rotating device $(0.5 \mathrm{rpm})$, kept at $15^{\circ} \mathrm{C}$ and illuminated with $10 \mu \mathrm{E} \mathrm{m} \mathrm{m}^{-2} \mathrm{~s}^{-1}$ light $(16: 8 \mathrm{~h})$. Prior to the experiments, O. marina was pre-adapted for $24 \mathrm{~h}$ to all experimental conditions, including food composition and concentrations. The algae used to restore the initial concentrations after the adaptation period, were also adapted to the low light conditions.

In the experimental and control bottles (i.e. with and without Oxyrrhis marina), cell concentrations and cell sizes of all species were followed for $48 \mathrm{~h}$. Measurements of $O$. marina (Expts 1, 2, and 3) and algal concentration and size distribution (except Micromonas pusilla) in Expt 1 were made on unpreserved samples using a 128-channel electronic particle counter (Particle Data Inc.). Algae in Expts 2 and 3 were measured without preservation applying flow cytometry (Coulter Epics XL) on the basis of their fluorescence characteristics (Fig. 1a, b). Calcified Emiliania huxleyi cells were distinguished from noncalcified cells by their side- 
Table 1. Experimental set-up with initial Oxyrrhis marina biovolume concentrations and initial cell sizes and biovolumes of the food algae. $n$ : number of replicates, ESD: equivalent spherical diameter

\begin{tabular}{|lllcc|}
\hline & $\begin{array}{c}\text { Oxyrrhis } \\
\text { marina } \\
\left(\mu \mathrm{m}^{3} \mathrm{ml}^{-1}\right)\end{array}$ & $\begin{array}{l}\text { Food algae } \\
\text { (species) }\end{array}$ & $\begin{array}{c}\text { Size } \\
(\mathrm{ESD}, \\
\mu \mathrm{m})\end{array}$ & $\begin{array}{c}\text { Cell } \\
\text { volume } \\
\left(\mu \mathrm{m}^{3}\right)\end{array}$ \\
\hline Expt 1 & $2.2 \times 10^{6}$ & Micromonas pusilla & 1.6 & 2 \\
$(\mathrm{n}=1)$ & & $\begin{array}{l}\text { Emiliania huxleyi } \\
\text { Tetraselmis suecica }\end{array}$ & 5.2 & 73 \\
Expt 2 & \multirow{2}{*}{$16.6 \times 10^{6}$} & Nannochloris sp. & 1.7 & 2 \\
$(\mathrm{n}=4)$ & & Isochrysis galbana & 5.0 & 64 \\
& & Rhodomonas sp. & 7.8 & 250 \\
& & Tetraselmis sp. & 9.8 & 492 \\
Expt 3 & $12.3 \times 10^{6}$ & Emiliania huxleyi & 4.7 & 5.5 \\
$(\mathrm{n}=4)$ & & Isochrysis galbana & 4.7 & 56 \\
\hline
\end{tabular}

scattering properties (flow cytometry, see Fig. 1c). Inverted microscopy was used to count preserved ( $2 \%$ acid Lugol's solution) samples of $M$. pusilla and to additionally control for the fraction of calcified $E$. huxleyi ( $1 \%$ glutaraldehyde).

Cell volumes of algae and Oxyrrhis marina were corrected by species-specific comparison with live cell volumes measured with an Image-Analysis-System (Leica Quantimet 570) at $500 \times$ or $125 \times$ magnification, respectively. Grazing rates were calculated from concentration changes of all species, including $O$. marina, in the experimental bottles compared to the controls following Frost (1972). Electivity-indices $(\alpha)$ were calculated from clearance rates and statistically tested, as described by Chesson (1983) for selection experiments with changing food densities. For display purposes, the $\alpha$ were transformed to $\varepsilon$, with $-1 \geq \varepsilon \leq+1$, following Chesson (1983).

Results. Due to the chosen light conditions, algal biovolume changes in the controls were insignificant (Figs. 2a, c \& 3a); therefore, rates of changes in the experimental bottles containing Oxyrrhis marina reflect grazing rates, which are listed in Table 2 . In the experimental bottles, biovolume concentrations significantly declined in the larger sized algae Tetraselmis suecica, Rhodomonas sp. and Tetraselmis sp. Within Expts 1 and 2 , O. marina grazed on these larger algae with higher clearance rates than on the smaller algae (Table 2).

Due to the much lower algal and higher Oxyrrhis marina concentrations used in Expt 2, rates of biovolume changes were higher than in Expt 1. In Expt 1, large cells remained through the $48 \mathrm{~h}$ of the experiment (Fig. 2b), whereas in Expt 2 they were almost totally removed within the first $6 \mathrm{~h}$ (Fig. 2d). Despite higher maximum clearance rates, the ingestion rates and biovolume-specific daily rations of $O$. marina were higher in the Expt 1 (Table 2), in which food density

a

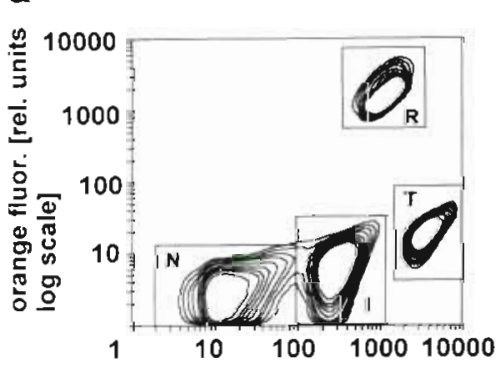

chlor. fluor. [rel. units log scale]

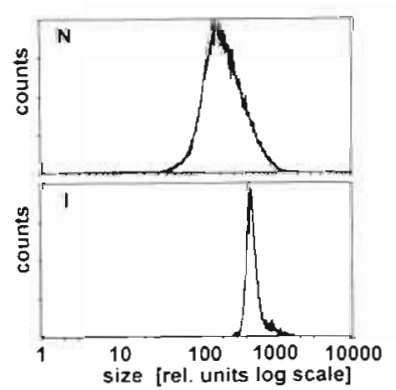

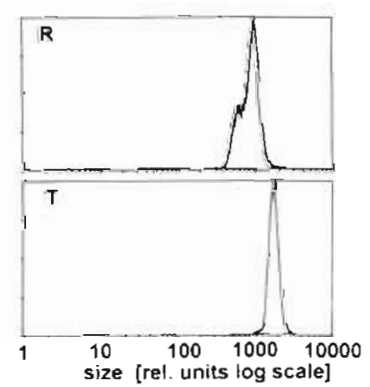

Fig. 1. Simultaneous measurement of different algal species by flow cytometry. (a) Expt 2. N: Nannochloris sp.; I: Isochrysis galbana; R: Rhodomonas sp.; T: Tetraselmis sp. (b) Expt 3. (c) Expt 3. Calcified and noncalcified Erailiania huxleyi cells b

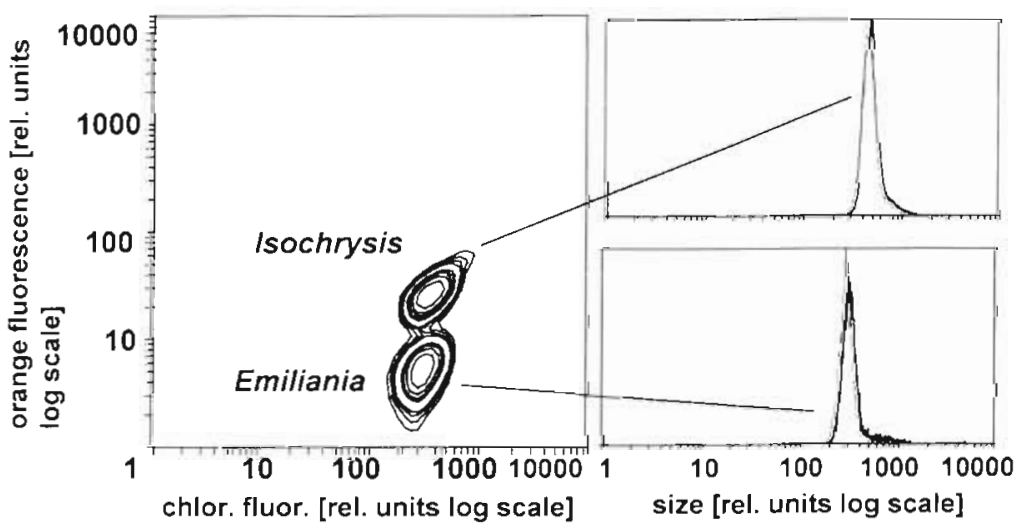

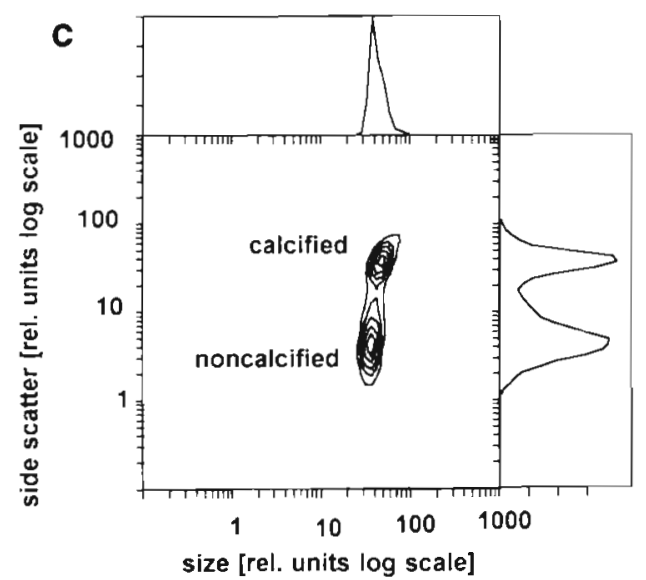


(a)
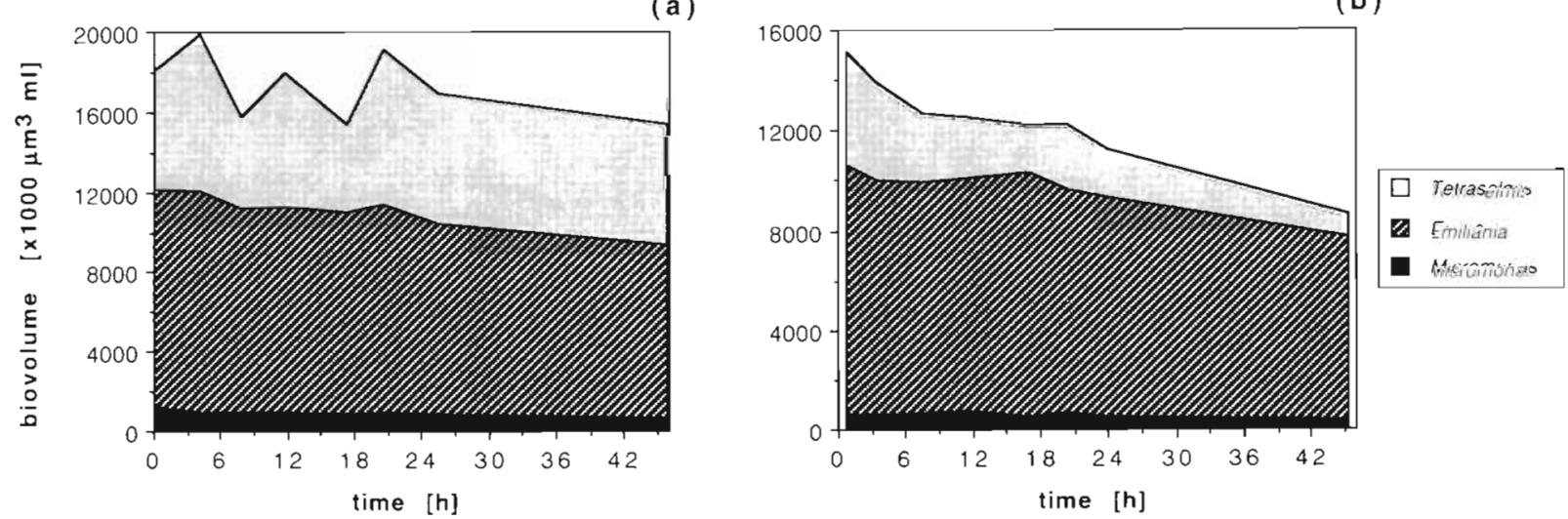

(c)
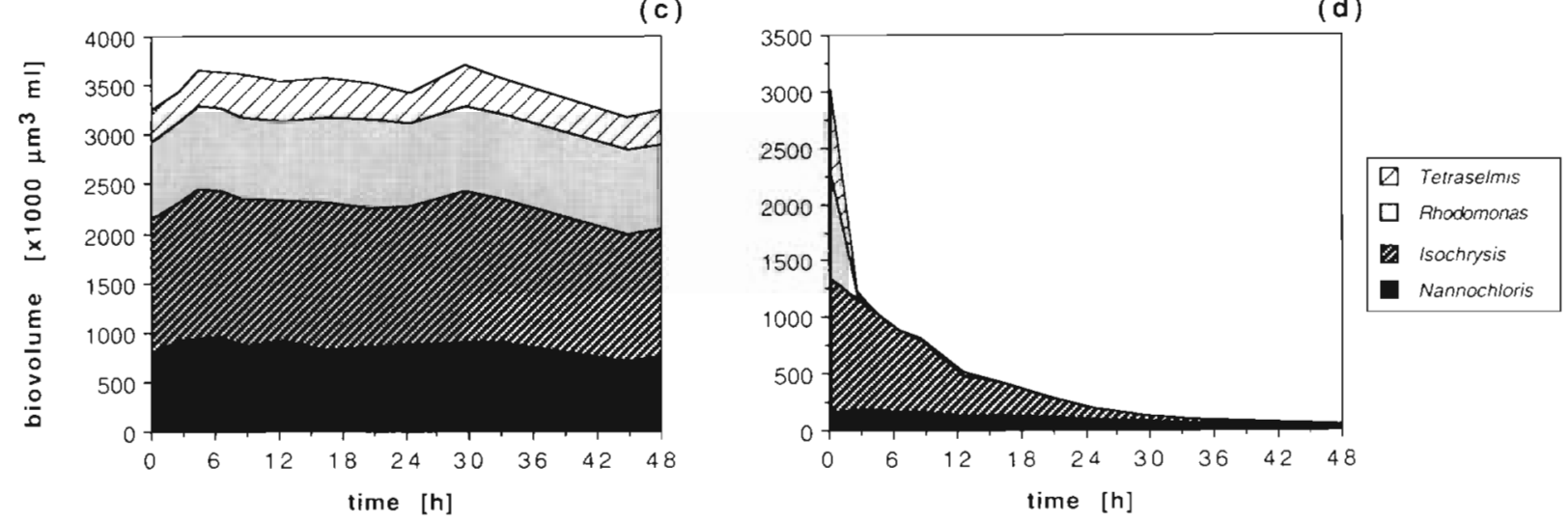

Fig. 2. Mean algal biovolume concentrations over $48 \mathrm{~h}$ in incubations without ( $\mathrm{a}, \mathrm{c}$; controls) and with ( $\mathrm{b}$, d) Oxyrrhis marina $(\mathrm{a}, \mathrm{b})$ Expt 1: Micromonas pusilla $(2 \mu \mathrm{m})$, Emiliania huxleyi $(5 \mu \mathrm{m})$ and Tetraselmis suecica $(7 \mu \mathrm{m})$. (c, d) Expt 2: Nannochloris sp. $(2 \mu \mathrm{m})$ Isochrysis galbana $(5 \mu \mathrm{m})$, Rhodomonas sp. $(8 \mu \mathrm{m})$ and Tetraselmis sp. $(10 \mu \mathrm{m})$. Note: there were 2 Tetraselmis species which were different in size (different shading)

was much higher. In both experiments, the moderately sized algae (Emiliania huxleyi and Isochrysis galbana, respectively) declined at a slower rate than did the larger algae, and concentrations changed least in the smallest algae, Micromonas pusilla and Nannochloris sp. (Fig. 2b, d).
Positive selection of the larger cells is explicitly demonstrated by the Chesson-indices (Fig. 4a ,b). As long as they were available at concentrations $\geq 20$ cells $\mathrm{ml}^{-1}$, the large Rhodomonas and Tetraselmis species were consumed in preference to the smaller algae. At even lower concentrations of these algae, Rhodomonas

(a)

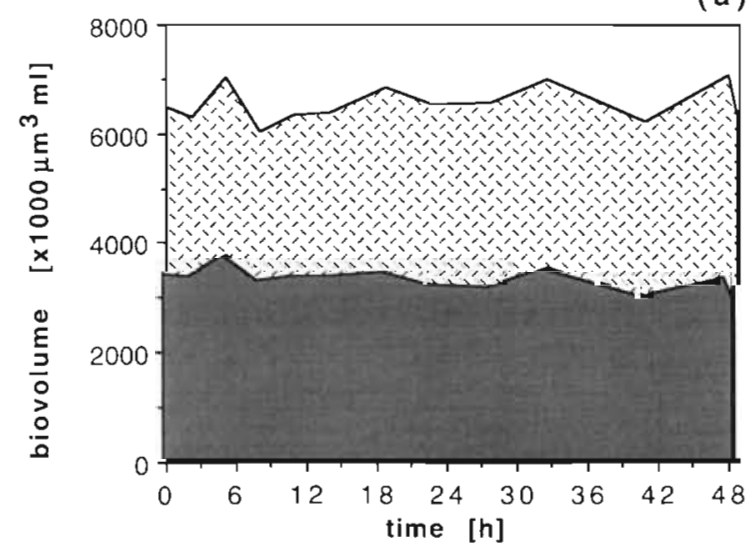

(b)

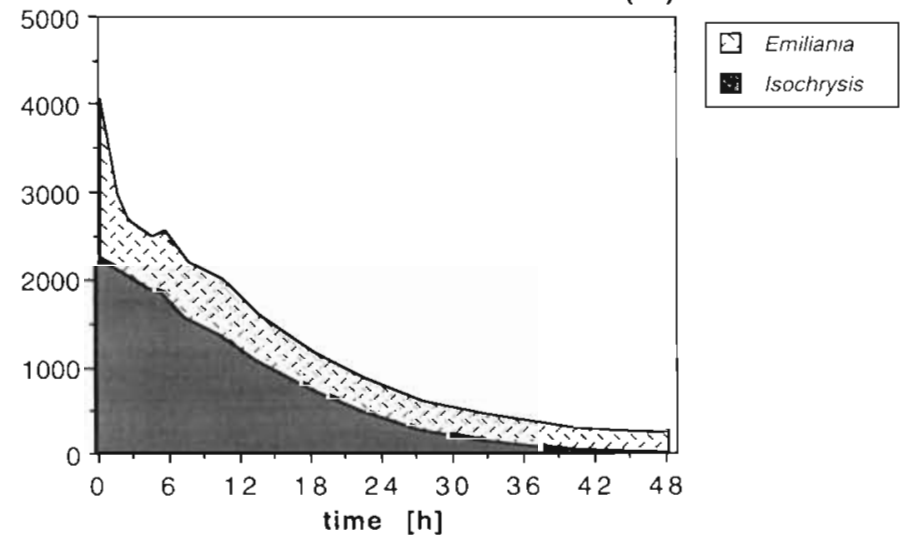

Fig. 3. Expt 3. Mean biovolume concentrations of Emiliania huxleyi and Isochrysis galbana over $48 \mathrm{~h}$ incubations without (a control) and with (b) Oxyrrhis marina 


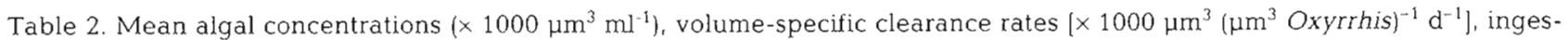
tion rates (cells Oxyrrhis $\left.{ }^{-1} \mathrm{~d}^{-1}\right)$ and volume-specific daily rations $\left(\% \mathrm{~d}^{-1}\right)$ for Oxyrrhis marina feeding on 7 different algal species during 3 incubation experiments

\begin{tabular}{|c|c|c|c|c|c|c|c|c|}
\hline \multirow{2}{*}{$\begin{array}{l}\text { Expt } \\
\text { no. }\end{array}$} & \multirow[t]{2}{*}{ Time } & \multirow[t]{2}{*}{ Food algae (species) } & \multicolumn{2}{|c|}{ Algal conc. } & \multicolumn{2}{|c|}{ Clearance rate } & \multirow{2}{*}{$\begin{array}{l}\text { Ingestion } \\
\text { rate }\end{array}$} & \multirow{2}{*}{$\begin{array}{c}\text { SDR } \\
1 \% d^{-1}\end{array}$} \\
\hline & & & Mean & SE & Mean & $\mathrm{SE}$ & & \\
\hline 1 & $00-12 \mathrm{~h}$ & Micromonas pusilla & 719 & - & -45 & - & -65 & -3.3 \\
\hline 1 & $12-24 \mathrm{~h}$ & Micromonas pusilla & 617 & - & 76 & - & 96 & 4.7 \\
\hline 1 & $24-48 h$ & Micromonas pusilla & 449 & - & 54 & - & 51 & 2.4 \\
\hline 1 & $00-12 h$ & Emiliania huxleyi & 9447 & - & -11 & - & -6 & -10.0 \\
\hline 1 & $12-24 \mathrm{~h}$ & Emiliania huxleyi & 9190 & - & 15 & - & 8 & 13.7 \\
\hline 1 & $24-48 h$ & Emiliania huxleyi & 7896 & - & 20 & - & 11 & 15.8 \\
\hline 1 & $00-12 \mathrm{~h}$ & Tetraselmis suecica & 3283 & - & 560 & - & 40 & 183.9 \\
\hline 1 & $12-24 h$ & Tetraselmis suecica & 2186 & - & 132 & - & 6 & 28.8 \\
\hline 1 & $24-48 \mathrm{~h}$ & Tetraselmis suecica & 1296 & - & 174 & - & 6 & 22.6 \\
\hline 2 & $00-06 \mathrm{~h}$ & Nannochloris sp. & 169 & 2 & 16 & 4 & 5 & 0.3 \\
\hline 2 & $06-24 \mathrm{~h}$ & Nannochloris sp. & 132 & 5 & 40 & 2 & 10 & 0.5 \\
\hline 2 & $24-48 h$ & Nannochloris sp. & 68 & 4 & 42 & 2 & 5 & 0.3 \\
\hline 2 & $00-06 \mathrm{~h}$ & Isochrysis galbana & 949 & 3 & 142 & 5 & 10 & 13.5 \\
\hline 2 & $06-24 \mathrm{~h}$ & Isochrysis galbana & 366 & 20 & 148 & 13 & 4 & 5.4 \\
\hline 2 & $24-48 \mathrm{~h}$ & Isochrysis galbana & 30 & 6 & 209 & 11 & 0 & 0.6 \\
\hline 2 & $00-06 \mathrm{~h}$ & Rhodomonas sp. & 126 & 2 & 1430 & 52 & 5 & 18.0 \\
\hline 2 & $06-24 \mathrm{~h}$ & Rhodomonas sp. & 1.3 & 0.0 & 225 & 31 & 0 & 0.0 \\
\hline 2 & $24-48 \mathrm{~h}$ & Rhodomonas sp. & 0.2 & 0.0 & 86 & 16 & 0 & 0.0 \\
\hline 2 & $00-06 \mathrm{~h}$ & Tetraselmis sp. & 77 & 6 & 1196 & 96 & 1 & 9.2 \\
\hline 2 & $06-24 \mathrm{~h}$ & Tetraselmis sp. & 6.1 & 0.5 & -43 & 42 & -0 & 0.0 \\
\hline 2 & $24-48 \mathrm{~h}$ & Tetraselmis sp. & 5.4 & 0.7 & -27 & 38 & -0 & 0.0 \\
\hline 3 & $00-02 \mathrm{~h}$ & Emiliania huxleyi & 1349 & 42 & 961 & 52 & 84 & 129.2 \\
\hline 3 & $02-12 \mathrm{~h}$ & Emiliania huxleyi & 663 & 12 & -21 & 6 & -1 & 0.0 \\
\hline 3 & $12-48 \mathrm{~h}$ & Emiliania huxleyi & 359 & 7 & 61 & 2 & 1 & 2.2 \\
\hline 3 & $00-02 h$ & Isochrysis galbana & 2185 & 16 & 87 & 6 & 11 & 18.9 \\
\hline 3 & $02-12 \mathrm{~h}$ & Isochrysis galbana & 1685 & 11 & 101 & 4 & 10 & 17.0 \\
\hline 3 & $12-48 \mathrm{~h}$ & Isochrysis galbana & 348 & 16 & 226 & 7 & 4 & 7.8 \\
\hline
\end{tabular}

sp. was still positively selected, but grazing on Tetraselmis sp. ceased (Fig. 4b, Table 2). A multivariate test on the Chesson-indices of the first period of Expt 2, when all algal species were sufficiently abundant, showed the preference for the large algal species to be significant $(\mathrm{p}<0.05$, Hotelling $t$-test).

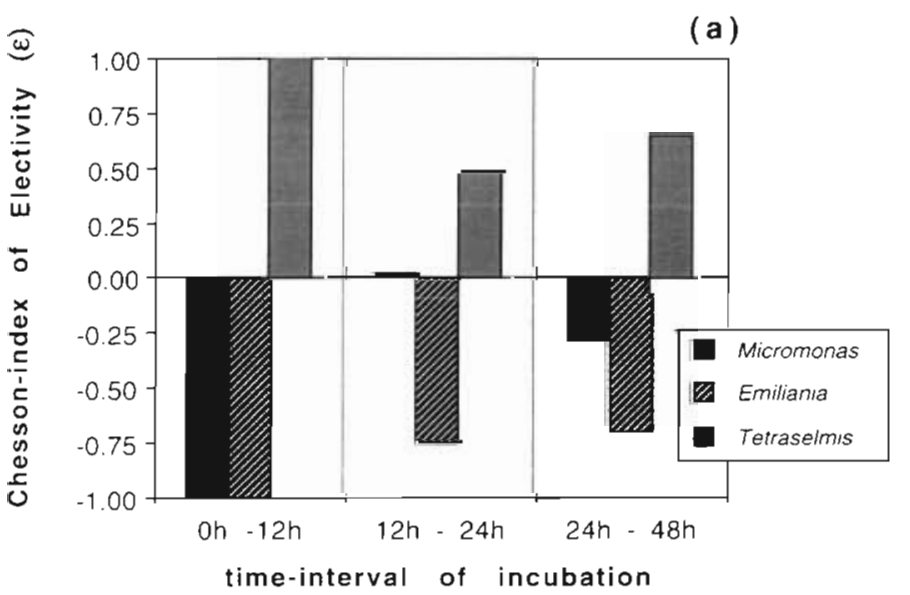

After $6 \mathrm{~h}$, when the concentrations of the large algae were diminished to very low levels, Oxyrhis marina fed primarily on the moderately sized Isochrysis galbana (Fig. 4b), which was grazed down during the rest of the experiment in preference to the small Nannochloris sp. (Figs. 2d \& 4b). The (negative) Chesson-

(b)

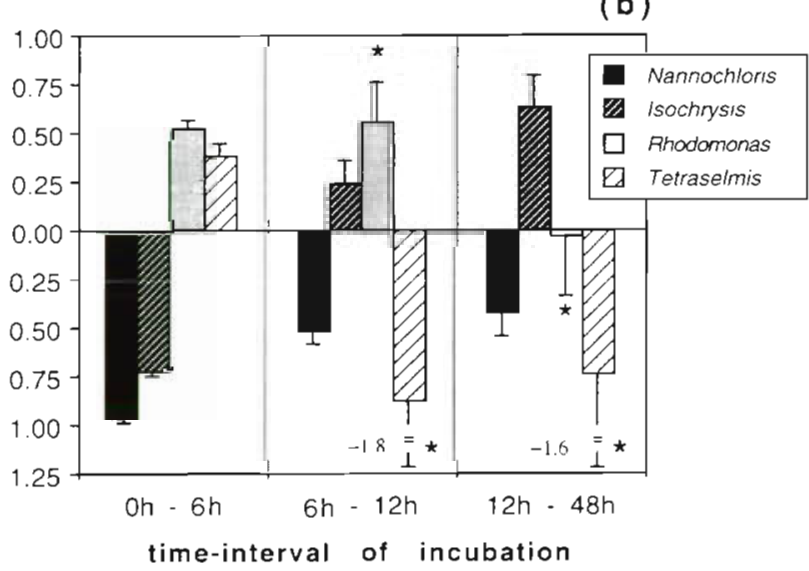

Fig. 4. Chesson-indices of Electivity $(\varepsilon)$ for Oxyrrhis marina simultaneously offered differently sized algal species (see Fig. 2): $-1 \leq \varepsilon \geq+1$, with $\varepsilon<0$ indicating negative, $\varepsilon>0$ positive, and $\varepsilon \approx 0$ no selective grazing. (a) Expt 1 . (b) Expt 2. * Large SD due to very low concentrations; mean $\pm \mathrm{SD}, \mathrm{n}=4$ 


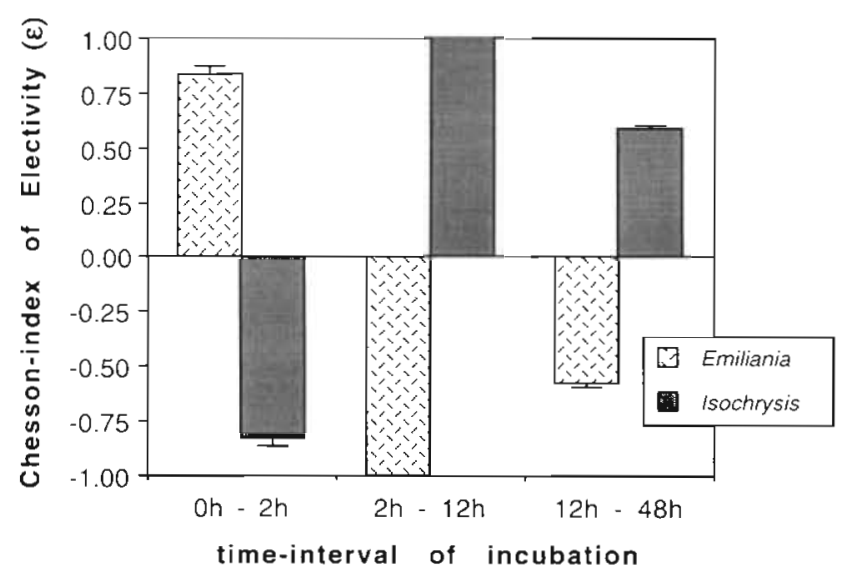

Fig. 5. Chesson-indices of Electivity $(\varepsilon)$ for Oxyrrhis marina simultaneously offered Emiliania huxleyi and Isochrysis galbana $-1 \leq \varepsilon \geq+1$, with $\varepsilon<0$ indicating negative, $\varepsilon>0$ positive, and $\varepsilon \approx 0$ no selective grazing. Mean $\pm \mathrm{SD}, \mathrm{n}=4$

indices of the smaller algae increased during the experiments, while the concentrations of the preferred, larger algae diminished. As a result, after $12 \mathrm{~h}$ the smallest species, Micromonas pusilla, was consumed almost in proportion to its abundance $(\varepsilon \approx 0$, Fig. 4 a) . However, considerable discrimination remained against the moderately sized and most abundant alga Emiliania huxleyi (Fig. 4a) and the small Nannochloris sp. (Fig. 4 b).

In Expts 1 and 2, Emiliania huxleyi was the only moderately sized alga that was selected against. More proof of a special feeding behaviour of Oxyrrhis marina towards E. huxleyi was demonstrated in Expt 3, where the similarly sized Isochrysis galbana and E. huxleyi were simultaneously offered. O. marina did not select against $E$. huxleyi in the first hours of the experiment. However, thereafter, O. marina preferred I. galbana (Figs. $3 \& 5$ ). All preferences were signifi-

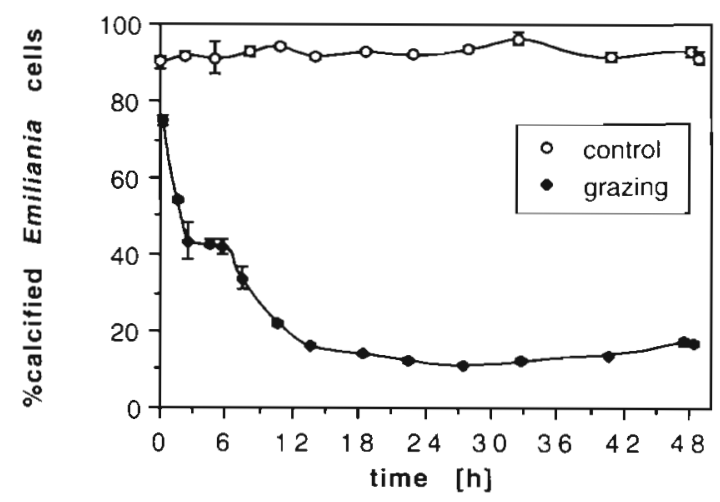

Fig. 6. Expt 3. Fraction of calcified Emiliania huxleyi cells (\% total E. huxleyi cell concentration) over $48 \mathrm{~h}$ incubations with (grazing) and without (control) Oxyrrhis marina. Mean $\pm \mathrm{SD}$, $\mathrm{n}=4$. Where error bars are invisible, they fall within the size range of the symbols

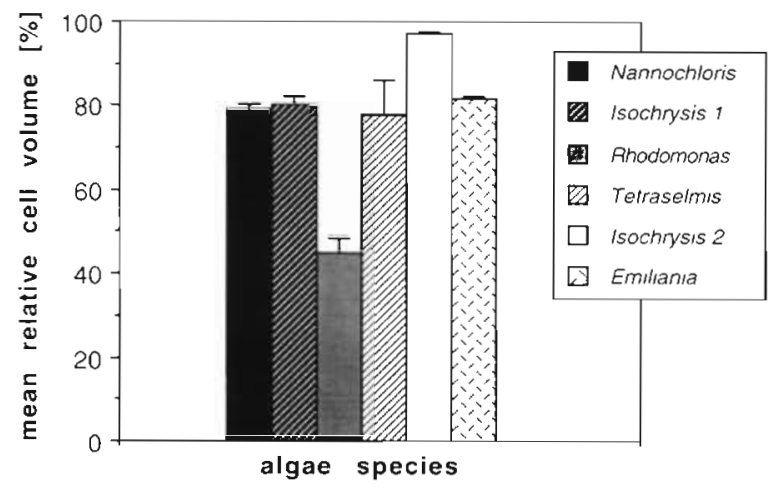

Fig. 7. Expts 2 and 3. Algal cell volume as \% of cell volume in controls after $24 \mathrm{~h}$ grazing (for Rhodomonas sp. and Tetraselmis sp. after 12 h) by Oxyrrhis marina. Mean \pm SD, $\mathrm{n}=4$

cant (Student's $t$-test, $\mathrm{p}<0.05$ ). While in the controls the percentage of calcified E. huxleyi cells remained constantly high $(92 \pm 2 \%)$, the percentage in the experimental bottles declined sharply to $17 \%$ (Fig. 6), indicating a strong selection for calcified over noncalcified cells of E. huxleyi.

After 24 h grazing by Oxyrrhis marina, the mean cell size in all algal species was significantly reduced $(\mathrm{p}<$ 0.01 , Student's $t$-test) in comparison to their sizes in the controls (Fig. 7). This indicates a preference of $O$. marina for larger cells within the species.

In Expt 3 controls, a daily rhythm in Emiliania huxleyi cell size was found. E. huxleyi showed synchronized cell growth, with cell division at the end of the dark period (Fig. 8), which is in accordance with observations by van Bleijswijk et al. (1994). However, such a rhythm was missing in the bottles with grazing, indicating that Oxyrrhis marina fed selectively on the actively growing and dividing cells.

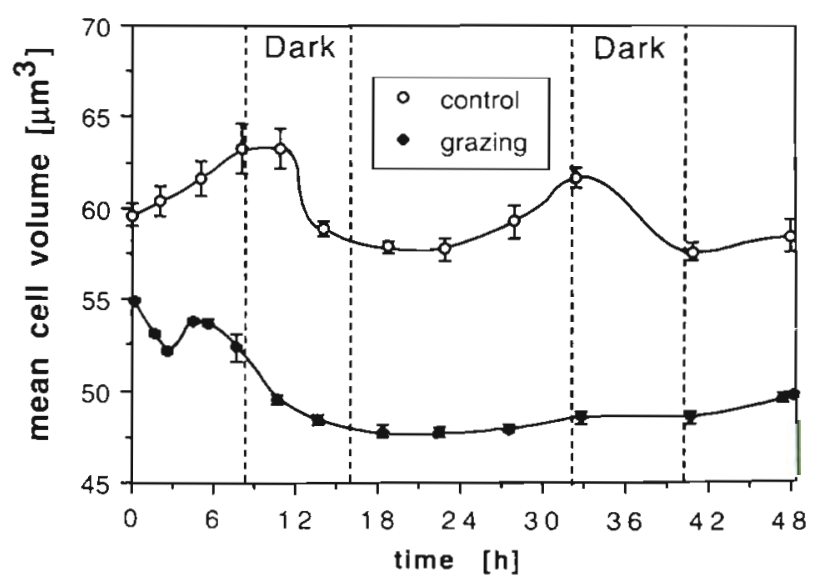

Fig. 8. Expt 3. Mean cell size in Emiliania huxleyi over $48 \mathrm{~h}$ incubations with (grazing) and without (control) Oxyrrhis marina. Mean $\pm \mathrm{SD}, \mathrm{n}=4$. Where error bars are invisible, they fall within the size range of the symbols 
Discussion. In Expts 1 and 2, initial concentrations of the different algal species were not equal and their proportions changed during the incubations. We applied the Chesson-index, which is especially suited to measuring selectivity under these conditions. It measures any deviation from random foraging independent of changes in food item concentrations, and does not change unless the behaviour of the grazer changes (Chesson 1983). According to optimal foraging theory for a predator handling individual prey items, selective behaviour towards a less preferred prey (i) is not influenced by the abundance of $i$, but by the abundance of the energetically more optimal, preferred prey (Charnov 1976). If the larger algae were the preferred prey, they would remain preferred irrespective of the abundance of the smaller algae. Thus, the relatively low biomass of the smallest algal species should neither have influenced the selective behaviour of Oxyrrhis marina towards themselves, nor towards the preferred, larger algal species.

The number of experiments and food species tested was limited, and food quality related properties other than size, e.g. biochemical clues (smell/taste), shape or mobility, may differ between the species tested and may also have affected grazing selectivity. Chemosensory ability has been shown to exist in flagellates (Bennett et al. 1988). However, selection experiments with Oxyrrhis marina grazing on a microalgae (Dunaliella terticolata) and flavoured and unflavoured latex beads suggested that $O$. marina is unable to distinguish particles on the basis of smell or taste (Tarran 1992). Cell shapes were not very different in our experiments: ovoid in case of Rhodomonas sp. and both Tetraselmis species and globoid in all other species. It is doubtful that $O$. marina could differentiate between such small differences in shape.

Grazing activity may be most directly documented by the clearance rate, which we expressed per unit biovolume of the grazer to account for differences in grazer size. Compared to Expt 1, maximum clearance rates were 2 to 3 times higher in Expts 2 and 3, indicating feeding saturation at the high initial food concentrations in the Expt 1 (Table 2). Maximum clearance rates and specific daily rations found in the first periods of the experiments were in the same range as reported in previous studies on Oxyrrhis marina (Tarran 1992 and references therein), and would allow growth rates up to 0.9 doublings $\mathrm{d}^{-1}$ (with $\sim 50 \%$ gross growth efficiency, Davidson et al. 1995). The specific daily rations found during the remainder of Expts 2 and 3 were too low to support growth of $O$. marina, which is in accordance with the observed small changes in their biomass (not shown)

The selection for larger particles was consistently found in all experimental treatments of this study and, obviously, size is a major selection criterium in Oxyrrhis marina. Size-selective grazing has also been shown for flagellates (Monger \& Landry 1991, Hansen 1992), and ciliates (Fenchel 1980, Jonsson 1986, Rassoulzadegan et al. 1988). Ciliates were shown to have an optimum prey size and their size-selectivity has been explained by the structure of their feeding apparatus (e.g. Fenchel 1980). In many flagellates such elaborate feeding structures are missing. The flagellate $O$. marina uses its tranverse flagellum to contact and capture the prey particles (Dodge \& Crawford $1971,1974)$. This flagellum is equipped with hair-like projections, which may have a function in particle selection. Tarran (1992) observed differential feeding by $O$, marina on microalgae, but ascribed selectivity rather to feeding history than to prey size. Therefore, O. marina was pre-adapted to the food compositions used in the experiments of this study. Hansen (1992) found size-selective grazing to occur in the dinoflagellate Gyrodinium spirale. G. spirale was shown to have an optimum prey size, which is similar to its own size. The size-related preference of $O$. marina for large particles (this study) is in accordance with the results for $G$. spirale. However, in O. marina, there was some indication for, relative to the size of the grazer, a lower optimum food size.

In the present multispecies study, grazing on Emiliania huxleyi occurred but, in most cases, a negative selection was found. The observed discrimination against E. huxleyi in Expt 1 can not be explained by its size, since $E$. huxleyi was intermediate in size to Micromonas pusilla and Tetraselmis suecica. Perhaps deterrent substances played a role. Grazing on the microalga Phaeocystis cf. globosa by copepods (Hansen \& van Boekel 1991) and by protozoans, including Oxyrrhis marina (Hansen et al. 1993), was also found to be very low, and DMSP (dimethylsulfoniopropionate)-related substances have been suggested to work as anti-grazing compounds (e.g. Estep et al. 1990). Whether a possible release of DMSPrelated substances by $E$. huxleyi played a role in our experiments is not known and remains speculative.

An exception to the discrimination against Emiliania huxleyi was the selection of the calcified over noncalcified E. huxleyi and in preferrence to Isochrysis galbana (Expt 2). Since calcified E. huxleyi are bigger than both other cell types, $89 \mu^{3}$ compared to $55 \mu^{3}$ and $57 \mathrm{\mu m}^{3}$ (apparent ESD at $t=0 \mathrm{~h}$ ), the preference for the calcified cells could be explained by size-selectivity. The possession of coccoliths does not seem to be an effective defence mechanism, as has been suggested (Young 1994). On the contrary, coccoliths make the cells larger and, in this study, more susceptible to grazing by Oxyxrrhis marina. Indeed, in experiments with E. huxleyi as the sole food or in bloom situations, graz- 
ing on E. huxleyi by microzooplankton (Holligan et al. 1993), including O. marina (Tarran \& Burkill 1995), has been shown.

One reason why microzooplankton may have a significant impact on Emiliania huxleyi populations is the preference, at least by Oxyrrhis marina, for the growing and dividing cells of E. huxleyi. If the grazers selectively remove the metabolically active fraction of an algal population, their impact would be much greater than would be estimated from numerical cell losses.

Hetero- and mixotrophic dinoflagellates form a substantial part of the herbivorous community. These organisms may show feeding behaviour like that observed for Oxyrrhis marina. However, it is clear that more investigations on selective grazing in heterotrophic dinoflagellates are needed.

Acknowledgements. We thank Mrs Anna Noordeloos for providing us with algal stock cultures. Dr Wim Klein Breteler and Dr Marcel Veldhuis are thanked for assistance in imageanalysis and flow cytometry. Mr Jaap van der Meer is thanked for mathematical and statistical advice. Furthermore, we are indebted to Dr Wim Klein Breteler, Dr Roel Riegman, Dr Marcel Veldhuis and Dr Judith van Bleijswijk for their valuable comments and Mr Paul Boudreau for linguistic improvements of the manuscript.

\section{LITERATURE CITED}

Bennet SJ, Sanders RW, Porter KG (1988) Chemosensory responses of heterotrophic and mixotrophic flagellates to potential food sources. Bull Mar Sci 43:764-771

Charnov EL (1976) Optimal foraging: attack strategy of a mantid. Am Nat 110:141-151

Chesson J (1983) The estimation and analysis of preference and its relationship to foraging models. Ecology 64(5) $1297-1304$

Davidson K, Cunningham A, Flynn KJ (1995). Predator-prey interactions between Isochrysis galbana and Oxyrrhis marina. IIr. Mathematical modelling of predation and nutrient regeneration. J Plankton Res 17(3):465-492

Dodge JD, Crawford RM (1971) Fine structure of the dinoflagellate Oxyrrhis marina II. The flagellar system. Protistologica 7(4):399-409

Dodge JD, Crawford RM (1976) Fine structure of the dinoflagellate Oxyrrhis marina III. Phagotrophy. Protistologica 10(2):239-244

Droop MR (1966) The role of algae in the nutrition of Heteramoeba clara Droop with notes on Oxyrrhis marina Dujardin and Philodina roseola Ehrenberg. In: Barnes H (ed) Some contemporary studies in marine science. Allan and Unwin, London, p 269-282

Estep KW, Nejstgaard J, Skjoldal HR, Rey F (1990) Predation by copepods upon natural populations of Phaeocystis

Responsible Subject Editor: J. Dolan, Villefranche-sur-Mer, France pouchetii as a function of the physiological state of the prey. Mar Ecol Prog Ser 67:235-249

Fenchel T (1980). Relation between particle size selection and clearance in suspension-feeding ciliates. Limnol Oceanogr $25(4): 733-738$

Frost BW (1972) Effects of size and concentration of food particles on the feeding behaviour of the marine planktonic copepod Calanus pacificus. Limnol Oceanogr 17:805-815

Guillard RRL, Ryther JH (1962) Studies of marine planktonic diatoms. I. Cyclotella nana Hustedt and Detonula confervacea Cleve. Can J Microbiol 8:229-239

Hansen FC, Reckermann M, Klein Breteler WCM, Riegman R (1993) Phaeocystis blooming enhanced by copepod predation on protozoa: evidence from incubation experiments Mar Ecol Prog Ser 102:51-57

Hansen FC, van Boekel WHM (1991) Grazing pressure of the calanoid copepod Temora longicornis on a Phaeocystis dominated spring bloom in a Dutch tidal inlet. Mar Ecol Prog Ser 78:123-129

Hansen PJ (1992) Prey size selection, feeding rates and growth dynamics of heterotrophic dinoflagellates with special emphasis on Gyrodinium spirale. Mar Biol 114: $327-334$

Holligan PM, Fernandez E, Aiken J, Balch WM, Boyd P, Burkill PH, Finch M, Groom SB, Malin G, M,ller K, Purdie DA, Robertson $C$, Trees C, Turner SM, van der Wal P (1993) A biogeochemical study of the coccolithophore Emiliania huxleyi in the North Atlantic. Global Biochem Cycles 7 (4):879-900

Jonsson PR (1986) Particle size selection, feeding rates and growth dynamics of marine planktonic oligotrich ciliates. Mar Ecol Prog Ser 33:265-277

Kofoid CA, Swezy O (1921) The free-living unarmored dinoflagellates. Memoires of the University of California 5, California Press, Berkeley

Lessard EJ (1991) The trophic role of heterotrophic dinoflagellates in diverse marine environments. Mar Microb Food Webs 5:49-58

Monger BC, Landry MR (1991) Prey-size dependency of grazing by free-living marine flagellates. Mar Ecol Prog Ser 74: $239-248$

Rassoulzadegan F, Laval-Peuto M, Sheldon RW (1988) Partitioning of the food ration of marine ciliates between picoand nanoplankton. Hydrobiologia 159:75-88

Tarran GA (1992) Aspects of the grazing behaviour of the marine dinoflagellate Oxyrrhis marina Dujardin. PhD thesis, University of Southampton

Tarran GA, Burkill PH (1995) Effects of temperature and concentration on the mortality and transformation of Emiliania huxleyi due to protozoan grazing. Conference on Emiliania huxleyi and the oceanic carbon cycle, The Natural History Museum, London, 5-8 April 1995 (abstract volume)

Van Bleijswijk JDL, Kempers R, Veldhuis MJ (1994) Cell and growth characteristics of types A and B of Emiliania huxleyi (Prymnesiophyceae) as determined by flow cytometry and chemical analysis. J Phycol 30:230-241

Young JR (1994) Function of coccoliths. In: Winter A, Siesser WG (eds) Coccolithophores. Cambridge Univ Press, Cambridge, p $63-82$

Manuscript first received: September 25, 1995

Revised version accepted: April 10, 1996 